\title{
MCDM analysis of wind energy in Turkey: decision making based on environmental impact
}

\author{
Sinem Değirmenci ${ }^{1} \cdot$ Ferhat Bingöl $^{2}$ (D) - Sait C. Sofuoglu ${ }^{1,3}$ \\ Received: 4 October 2017 / Accepted: 11 April 2018 / Published online: 8 May 2018 \\ (C) Springer-Verlag GmbH Germany, part of Springer Nature 2018
}

\begin{abstract}
Development of new wind energy projects require complex planning process involving many social, technical, economic, environmental, political concerns, and different agents such as investors, utilities, governmental agencies, or social groups. The aim of this study is to develop a tool combining Geographic Information System (GIS) and Multi-Criteria DecisionMaking (MCDM) methodologies, and its application for Turkey as a case study. A variety of constraints and criteria were identified based on a literature review and regulations gathered from variety of agencies, use of which resulted in determination of infeasible sites. Then, pairwise comparisons were carried out using analytic hierarchy process as the MCDM method to estimate relative importance of the criteria, and to visualize a suitability map with three classes. As the final stage, decision making was carried out based on environmental impact where $45.5 \%$ of the Turkish territory was found as infeasible area. Sixty percent of the remaining area are covered by the moderate suitability class, followed by the highly suitable area (20.3\%) and low suitable area (19.8\%). The output of this study can be used by energy planners to estimate the extent that wind energy can be developed based on public perception, administrative, and environmental aspects.
\end{abstract}

Keywords Wind $\cdot$ Energy $\cdot$ Environmental impact $\cdot$ MCDM $\cdot$ AHP $\cdot$ GIS

\section{Introduction}

Electrical energy is required for economic growth and human populations. Although it is mainly obtained from conventional sources such as coal, oil, and natural gas, environmental impacts caused by conventional sources are much worse than those brought about by the use of renewable energy sources (RES) (Góralczyk 2003; Weisser

Responsible editor: Philippe Garrigues

Electronic supplementary material The online version of this article (https://doi.org/10.1007/s11356-018-2004-4) contains supplementary material, which is available to authorized users.

Ferhat Bingöl

ferhatbingol@iyte.edu.tr

1 Department of Environmental Engineering, Izmir Institute of Technology, Gulbahce, Urla, 35430 Izmir, Turkey

2 Department of Energy System Engineering, Izmir Institute of Technology, Gulbahce, Urla, 35430 Izmir, Turkey

3 Department of Chemical Engineering, Izmir Institute of Technology, Gulbahce, Urla, 35430 Izmir, Turkey
2007; Kumar et al. 2016). Therefore, RES have become promising alternatives to non-renewable sources. RES include natural sources such as wind, solar, thermal, photovoltaic, hydro, wave, tidal, biofuels, ocean, and geothermal sources (Twidell and Weir 2015). Utilization of RES such as wind reduces emission of $\mathrm{CO}_{2}$ and other greenhouse gases (GHG), and hazardous air pollutants, increases water conservation; provides domestic job creation; landowner revenue generation and rural tax revenue; and perhaps most importantly, reduce reliance on fossil fuels for electricity generation (AWEA 2008). Specifically, the impacts of wind energy are low, local, and manageable (Bilgili and Simsek 2012).

Turkey is one of the fastest growing power markets in the world and was positioned in the global wind energy market as the 10th largest annual market in 2015. Turkey's first commercial wind farm was commissioned in Alaçatı, Çeşme, in 1998 with a capacity of 1.5 MW (Ilk1liç et al. 2011). Even though the first wind farm started operation in Turkey as early as 1998, investments significantly increased after 2005 with the adoption of "The Renewable Energy Law of Turkey." The market has grown from $20 \mathrm{MW}$ in 2006 to $4700 \mathrm{MW}$ in 2016 (TWEA 2016). Turkey's primary energy reserves are not 
enough to meet the rising energy demand. Currently, there are 3.144-GW acquired wind farm licenses waiting to be built.

Europe, specifically the EU states, has a goal of at least $27 \%$ renewable energy consumption in final energy consumption at European level until 2030 (EWEA 2015). Turkey has a similar target of increasing the installed capacity to $20 \mathrm{GW}$ until 2023 (Dursun and Gokcol 2014). Since geographical limitations, public opposition, wildlife conservation, and electricity grid integration pose challenges for the investors, not much space is available for the implementation of wind farms. These factors make planning of wind power plants to become a complex procedure, involving the consideration of many different criteria and constraints. The most important consideration in site selection for wind turbines is the wind energy density, but technical, economic, environmental, social, and political requirements have started being considered efficaciously. Economic issues are associated with maximizing economic benefit, and environmental concerns aim to decrease the adverse effects of the wind farms. Environmental concerns include impacts on humans (e.g., noise, visual effect) and effects on ecosystems (e.g., the damage to the wildlife, especially birds and bats, and habitat loss). The acceptance of wind farms and socio-political parameters are two difficult points that have been imbedded in the Environmental Impact Constraints (EIC) and should be discussed by the developer and other parties involved, after the output of MCDM tools results are extracted.

The complex decision-making process requires a tool that can incorporate a set of decision alternatives and the decision maker's preferences effectively. In a Geographical Information System (GIS)-based decision-making process, the alternatives are evaluated by preferences of individuals (decision makers, managers, stakeholders, interest groups) with utilization of Multi-Criteria Decision-Making (MCDM) that contributes a methodology for guiding the decision maker, whereas GIS provides processing of the geographic data. Therefore, GIS and MCDM methods combine and transform geographic data and the decision maker's preferences into a resultant decision, and allow to reach optimal solutions for highly complex spatial decision-making problems (Malczewski 2010). The major advantages of using a GIS-based approach for siting is to reduce the time and cost of site selection, and also to provide a digital data bank for long-term monitoring of the site (Moeinaddini et al. 2010). Therefore, GIS is widely used in the decision and management situations such as environmental planning and management, transportation planning and management, urban and regional planning, waste management, hydrology and water resource, agriculture and forestry, geology and natural hazard, and real estate and industrial facility management (Malczewski 2010).

One of the first studies regarding the evaluation of the wind energy potential has been carried out by Voivontas et al. (1998) for the island of Crete, Greece, using a $250-\mathrm{kW}$ wind turbine. In recent years, there are several studies of GIS applied to site selection of wind farms around the world including Turkey. Studies differ from each other with respect to choice of the study area, the criteria, and the methodologies applied. Short list of studies compiled by the authors are from several countries such as Austria (Gass et al. 2013), Belgium (Lejeune and Feltz 2008), Cyprus (Georgiou et al. 2012), Denmark (Hansen 2005), Germany (Höfer et al. 2016), Greece (Tegou et al. 2010; Latinopoulos and Kechagia 2015), Iran (Noorollahi et al. 2016), Oman (Al-Yahyai et al. 2012), Poland (Sliz-Szkliniarz and Vogt 2011), Spain (Sánchez-Lozano et al. 2014; Schallenberg-Rodríguez and Notario-del Pino 2014), Thailand (Bennui et al. 2007), Turkey (Aydin et al. 2010; Atici et al. 2015), the UK (Baban and Parry 2001; Watson and Hudson 2015), and the USA (Van Haaren and Fthenakis 2011; Grassi et al. 2012; Gorsevski et al. 2013). While some of them focus on the national scale (Al-Yahyai et al. 2012; Gass et al. 2013), the others were conducted on regional scale. Parameters of interest vary from country to country, even sometimes region to region based on the legal framework enforced by governments. MCDM have been used by different methods like Elimination and Choice Translating Reality (SánchezLozano et al. 2014; Atici et al. 2015), Stochastic Multiobjective Acceptability Analysis (Atici et al. 2015), Order Weighted Averaging (Baban and Parry 2001; Aydin et al. 2010; Al-Yahyai et al. 2012), Analytical Hierarchy Process (Baban and Parry 2001; Bennui et al. 2007; Tegou et al. 2010; Al-Yahyai et al. 2012; Georgiou et al. 2012; Latinopoulos and Kechagia 2015; Watson and Hudson 2015; Höfer et al. 2016), Simple Additive Weighting (Hansen 2005; Georgiou et al. 2012; Gorsevski et al. 2013), and Weighted Index Overlay (Noorollahi et al. 2016).

This study presents a GIS-based multi-criteria decisionmaking model applicable to diverse terrain and climatology conditions, that accounts air density for wind speed, that can be updated with changing regulations, that integrates environmental impact into the selection at the last stage among those remain after application of the technical/economic criteria, and that has been validated by comparing locations of $>100$ in-operation wind farms, which all give form to a unique study with regard to the literature. Nevertheless, nationwide studies are scarce in the literature and Turkey has not been studied based on Turkish regulations or there is no such model in use in Turkey for wind farm planning.

\section{Theory and method}

The proposed methodology for site selection of wind power plant installation in Turkey, which is illustrated in Fig. 1, was handled under four stages. In the first stage, decision-making criteria associated with energy generation of wind turbines were identified 
Fig. 1 Overview of the methodology

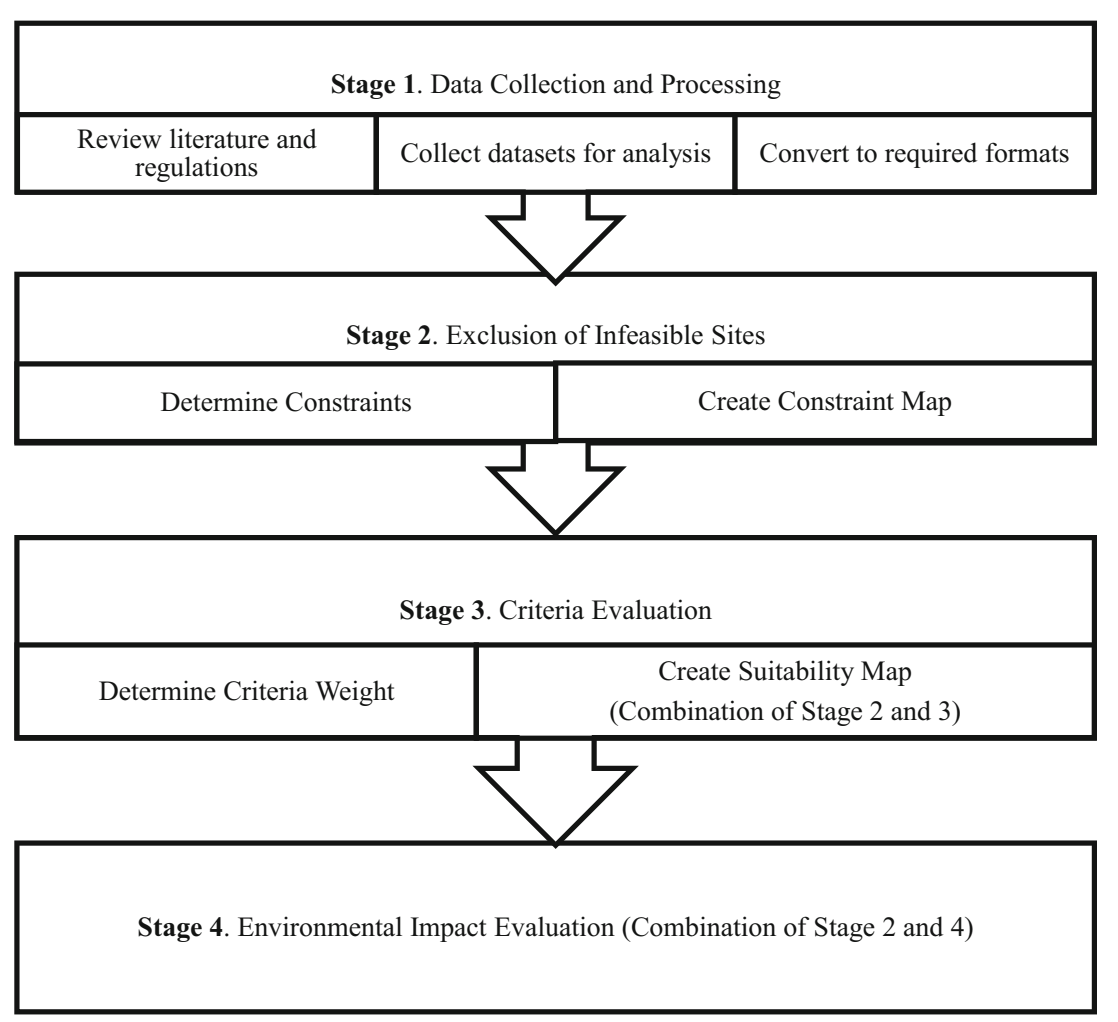

based on a review of the literature and the regulations. Then, boundaries and geographical coordinates of these factors were collected and processed in GIS. In the next step, infeasible sites were excluded depending on regulations and planning constraints. In the third stage, the remaining sites were evaluated based on the economical and technical characteristics of the study area. The evaluation at this stage was conducted with a multiplecriteria decision-making method. In the last stage, the areas were evaluated with the environmental objectives adopting a conservative approach (i.e., implementing exclusion areas) to show potentially problematic sites and suitable locations for wind turbines.

\section{Study area: Turkish territory}

Turkey, located between $36^{\circ}-42^{\circ}$ North latitude and $26^{\circ}$ $-45^{\circ}$ East longitude, is a large peninsula that bridges the continents of Europe and Asia. The country has a small part in Europe and a large area in Asia called Thrace and Anatolia, respectively. Turkey is surrounded by sea on three sides: the Black Sea, the Mediterranean Sea, and the Aegean Sea. Turkey is divided into 81 provinces in seven geographical regions. All the provinces and regions might apply different cost and/or environmental criteria. Its total area is 78 million hectares of which 21.7 million hectares are designated as forest area (TUIK 2014).

\section{Multi-criteria decision-making methods and AHP}

The application of MCDM techniques is gaining popularity in renewable energy management (Pohekar and Ramachandran 2004). The aim of traditional single criteria decision making in energy investments was maximization of net benefits, in monetary terms. As the energy management problems are getting more complex, economic considerations are complemented with environmental and social considerations, leading to multiple-criteria decision making being used to deal with conflicting decision problems.

There is a wide range of MCDM methodologies, based on their goals and application steps, and how the alternatives are ranked. For energy planning applications, the Analytical Hierarchy Process (AHP) is popular and recommended (Pohekar and Ramachandran 2004) because of its simplicity, flexibility, and especially its ability to mix qualitative as well as quantitative criteria in the same decision framework, which was followed in this study. The basic principles can be summarized as follows; however, a detailed description of the methodology employed in this study is provided in Supporting Document-1: AHP, a hierarchy is a MDCM approach where criteria are organized in a hierarchic structure in such a way that each level may represent a different section at the problem. Once each of the levels is defined, the method derives priority scales or weights through a series of pairwise comparisons (Saaty 1980). The pairwise comparisons are the core of 
the AHP process and they determine the relative importance of one criterion over another (Saaty 2008). Evaluations can be based on measurable quantities or people's perceptions and preferences, in which case the need and purpose of the decision and the effects on various stakeholders come strongly into play. Finally, the alternatives are ranked in terms of combination of the criteria scores. Additionally, the method has a special provision for the consistency in the judgements of each individual evaluator assigning scores.

\section{Data collection and processing}

All land with adequate or optimum wind energy resources may not be equally suitable for wind energy development. For example, certain areas may be declared as protected land by the governmental regulations, or they may be located at a significant distance from available roads, which significantly increases construction costs. Therefore, all objectives/possible factors associated with site selection for wind turbines were identified based on national legislation related to wind turbine development and literature research. A set of factors were finally selected and the boundaries and geographical coordinates of those factors were collected from government agencies, web-based datasets, scientific studies, and a voluntary agency (Table 1) which were then processed in GIS. Factors were classified into three categories, based on a logical sequence of application (schematic diagram).

- Exclusion Parameters (political concern)

- Evaluation Criteria (economical and technical concern)

- Environmental Impact Constraints (environmental and social concern)

Data sources (and other information) are presented for each factor in Table 1.

In addition, a detailed description of the rationale for the inclusion of each factor and the definitions of elements/classes/ thresholds are given in the Supporting Document-2. It should be emphasized here that the inclusion of further factors in the site suitability analysis was also considered, such as location of protected forests, world heritage sites, natural sites, military districts, bat habitats, and bird migration routes. However, these

Table 1 Spatial analysis layers

\begin{tabular}{|c|c|c|}
\hline Step & Layer & Source of data \\
\hline \multirow[t]{6}{*}{ Exclusion Parameters (political concern) } & Radars & $\begin{array}{l}\text { Turkish Republic Official Journal (Number: 29033) (Legistration on } \\
\text { Prelicence of Wind and Solar Power 2014) }\end{array}$ \\
\hline & Airports & $\begin{array}{l}\text { CORINE } 2002 \text { Seamless Vector Data (CLC: 124), } \\
\text { Energy Market Regulatory Authority Announcement in 12th of May, } 2016\end{array}$ \\
\hline & Fault lines & Kandilli Observatory and Earthquake Research Institute (KOERI 2015) \\
\hline & Urban areas & CORINE 2002 Seamless Vector Data (CLC: 111, 112) \\
\hline & Protected areas & $\begin{array}{l}\text { Directorate of Nature Conservation and National Parks (Coordinates of } \\
\text { Special Environmentally Protected Areas 1990, 2000, 2004, 2007, 2010, } \\
\text { 2013; Law on Wildlife Protection and Development Areas 2004), } \\
\text { UNESCO (UNESCO 2016a, b) }\end{array}$ \\
\hline & Altitude & SRTM 4.1 DEM (Jarvis et al. 2008) \\
\hline \multirow{7}{*}{$\begin{array}{l}\text { Evaluation Criteria (economical and technical } \\
\text { concern) }\end{array}$} & Air density & ‘Adaptation of Uniform Wind Atlases’ (Bingöl 2016) \\
\hline & Wind speed & Global Wind Atlas (DTU 2016) \\
\hline & Frozen period & WorldClim (Hijmans et al. 2005) \\
\hline & Land cost & The Revenue Administration (Turkey 2014) \\
\hline & Roads & OpenStreetMap (OpenStreetMap 2015) \\
\hline & Grid capacities & TEİAȘ (TEIAS 2015) \\
\hline & terrain Complexity & ‘Adaptation of Uniform Wind Atlases’ (Bingö1 2016) \\
\hline $\begin{array}{l}\text { Evaluation Criteria and Environmental Impact } \\
\text { Constraints (economical and environmental } \\
\text { concern) }\end{array}$ & Forest & $\begin{array}{l}\text { CORINE } 2002 \text { Seamless Vector Data (CLC: } 311,312 \text { and 313), (Regulation } \\
\text { for Article } 18 \text { of the } 17 / 3 \text { of the Forest Law 2014) }\end{array}$ \\
\hline \multirow{4}{*}{$\begin{array}{l}\text { Environmental Impact Constraints (environmental } \\
\text { and social concern) }\end{array}$} & Agricultural lands & CORINE 2002 Seamless Vector Data (CLC: 212) \\
\hline & Bird habitat & Doğa Derneği (KusBank Veritabanı, Doğa Derneği 2016) \\
\hline & Visual impact & $\begin{array}{l}\text { The study of 'Identification of Visual Influence Zones of Wind Farms in } \\
\text { Lithuania' (Abromas and Kamičaitytė-Virbašienė 2014) }\end{array}$ \\
\hline & Noise & $\begin{array}{l}\text { Regulation on Assessment and Management of Environmental Noise } \\
\text { (Regulation on Assessment and Management of Environmental Noise } \\
\text { 2008) }\end{array}$ \\
\hline To validate results & Farms areas & Energy Market Regulatory Authority (EMRA 2015) \\
\hline
\end{tabular}


datasets were either not accessible or not available, due to security regulations or were simply not shared with the public by the authorities.

\section{Generic wind turbines}

An additional consideration in our study pertains to the different wind potential calculation for different wind turbine models (criterion "Wind potential" of step 2-Technical and economical evaluation criteria). Given that more than 50 wind turbine models have been developed over the last decade, it was deemed impractical to create a separate evaluation/decision-making tool for each of them. Additionally, environmental impacts of bigger and smaller turbines differ from each other (Tremeac and Meunier 2009). Therefore two different wind turbines representing the 900-kW (50-m hub height) and 2.1-MW (100-m hub height) classes, which are frequently used, were chosen for this study (Table 2). Capacity factors of the defined turbines were acquired from Hughes (2012) who collected onshore wind datasets on substantial installations. Capacities were calculated by taking the averages of lifetime efficiency of the turbines that have the same power rate with the generic turbines and found as $22 \%$ for $900 \mathrm{~kW}$ and $31 \%$ for $2.1 \mathrm{MW}$.

\section{Data analysis}

The data analysis was performed following the step-wise processing algorithm described in the "Theory and method" section. In the first step (Exclusion of Infeasible Sites), layers representing exclusion zones for wind farms were collated, merged, and dissolved. In the second step (Criteria Evaluation), technical and economical criteria were assigned weights through pairwise comparisons, the values of the GIS layers were scaled and used in the calculation of coefficients for the final decision-making atlas. Finally, when the user reaches the last step, a very few number of places are left

Table 2 Properties of the generic wind turbines

\begin{tabular}{|c|c|c|}
\hline Characteristic & $\begin{array}{l}\text { Generic turbine } \\
1\end{array}$ & $\begin{array}{l}\text { Generic turbine } \\
2\end{array}$ \\
\hline Hub height (m) & 50 & 100 \\
\hline Diameter (m) & 45 & 80 \\
\hline Swept area $\left(\mathrm{m}^{2}\right)$ & 1590.4 & 5026.5 \\
\hline Power (kw) & 900 & 2100 \\
\hline Capacity factor $(\%)$ & 0.22 & 0.31 \\
\hline Total turbine cost $(€)$ & 680,000 & 1.580 .000 \\
\hline O\&M cost $(€)$ & 680,000 & 1.580 .000 \\
\hline $\begin{array}{l}\text { Gross yearly income from electric } \\
\text { sale }(€)\end{array}$ & 125.000 & 375.000 \\
\hline Net income annually $(€)$ & 25.000 & 175.000 \\
\hline
\end{tabular}

which can be compared among each other. Now, the user can choose one against other (maybe between top two best locations) based on environmental impact criteria to finalize the case study.

An exclusion zone is an unsuitable zone for wind turbine installation based on legal regulations and literature review. In some cases, buffer zones are also taken into account to define the minimum distance around those areas. The raw data, in the form of GIS vector layers, were used to create exclusion zones by adding buffers. Any site that is outside the below listed buffers is assumed to be "a technically feasible site".

- Radar locations with 5-km buffer zones around them (Legistration on Prelicence of Wind and Solar Power 2014),

- Airports with 3-km buffer zones around them (According to the Turkish legislation prior to 2016 (Legislation for Construction Criteria Around the Airports 2012))

- 2- and 15-km buffer zones around aeronautical stations and navigational aids, respectively (Energy Market Regulatory Authority announcement on 12th of May, 2016)

- Fault lines with 150-m buffer zones around them (Demirtaş 2005)

- Urban areas with 1-km buffer zones areas around them (applicable to cities only) (Regulation on the Technical Assessment of Applications related to Wind Power Generation 2015)

- $\quad$ Protected areas (Forest Law 1956; Law on National Parks 1983; Law on Protection of Cultural and Natural Properties 1983; Coordinates of Special Environmentally Protected Areas 2004; Law on Wildlife Protection and Development Areas 2004)

- Areas with an elevation above 1500 m (REPA 2007)

Each vector layer created in order to define the exclusion zones was subtracted from the borders of Turkey. As the regulation regarding airports was changed during the study, two different suitability maps with the new and old regulation were developed to illustrate the suitability levels within the feasible sites.

After assessing the technically feasible sites, economically optimum sites were obtained in the next step using the pairwise comparisons of criteria weights in combination with scaled numerical values of each criterion/variable. Firstly, data of each layer were converted from vector format to a raster format and resampled to ${ }^{1} / 120^{\circ}$ cell sizes (around $700 \times 900 \mathrm{~m}$ ) to obtain raw data of all criteria in grid format, and each of these grid cells was considered as a potential location for installation of wind farms. Secondly, the numerical values for each criterion were scaled from 0 to 100 based on their maxima and minima. The calculation for wind power was repeated for two generic wind turbines defined in Table 2. The scaling factor is applied to criteria as 
100 being the most positive and 0 is being the most negative effect to the decision-making steps. Therefore; wind power, roads density, and grid capacities were scaled as a positive impact, and the factors of land cost and frozen periods were scaled as negative impact (Table 3). The forested terrains warranted a special consideration. In order to visualize forested terrain areas, non-vegetated areas were taken from CORINE 2002. Seamless Vector Data were combined with the rental agreement regional prices (Regulation for Article 18 of the 17/3 of the Forest Law 2014). Although these areas were classified according to their fees and the regions having lowest prices represented high preferability, the non-vegetated areas were defined with the highest score in order to minimize any forest loss.

Subsequently, the relative importance of each layer was assigned by an expert group. The relevant priorities for the pairwise comparisons were provided by the expert group comprised of two academicians, one manager of a company, one project engineer, and two graduate students, utilizing a preference scale of 1 to 9 as recommended by Saaty (Saaty 2008). Please see Supporting Document -1 for details. Since there is a lack of expertise regarding the ruggedness index calculation and usage, the weight of altitude was assigned by only one expert from the group to avoid inconsistencies. For the other parameters, mean values were used. A Consistency Index (CI) was also calculated to evaluate the consistency in the judgement of each expert (see Supporting Document-1).

To obtain the priority vector for each criterion, the $\mathrm{n}^{\text {th }}$ root value method was applied with $n=7$ for this study. Dividing each row to sum of the $\mathrm{n}^{\text {th }}$ root column in gives the priority vector. The suitability scores per criterion per grid cell were calculated by multiplying the priority vector with the scaled values for each criterion, and then summing across criteria to obtain the overall suitability index. Then, the map thus created was divided into three classes according to the overall suitability score. The classes having higher score represent better suitability: low suitable (scores between 2000 and 4000), moderately suitable (scores between 4000 and 6000), and highly suitable (scores > 6000 ).

Although comprehensive studies should be conducted for the Environmental Impact Assessment (EIA), our work in the third stage aims to provide a preliminary step for the detection of

Table 3 Scaling rules for the raw data of the evaluation criteria

\begin{tabular}{lll}
\hline & Factors & Type $(\min / \max )$ \\
\hline 1 & Wind power & Max \\
2 & Frozen period & Min \\
3 & Land cost & Min \\
4 & Roads & Max \\
5 & Forest & Special consideration \\
6 & Grid capacities & Max \\
7 & Terrain complexity & Min \\
\hline
\end{tabular}

adverse environmental effects of wind power plants. The objective of this stage was to evaluate the project sites in terms of primary environmental aspects and the potential for environmental concerns to arise. The primary environmental issues were classified as forests, agricultural areas, important bird areas, noise, and visual impact. With respect to the first two constraints, removal of vegetation for the construction of power plants can cause fragmentation and loss of habitat. It has been estimated that approximately 1.23 ha of vegetation is removed per wind turbine (Zimmerling et al. 2013). The road and grid infrastructure are added up to habitat loss.

Although actual habitat loss changes based on local circumstances, the predicted habitat loss for Turkey based on this average loss per turbine and the number of turbines constructed in Turkey according to previous studies was approximately 2063 ha (TWEA 2015). Moreover, habitats in the vicinity of wind farms may not be preferred for foraging, nesting, and roosting during their construction activities and operation by some bird species depending on their life history, behavior, and habitat requirements (Zimmerling et al. 2013).

For the purposes of this particular step, all forest and agricultural areas were considered as areas of concern. Visual impacts were explored with two buffer zones, $20 \mathrm{~km}$ from wind turbines, a distance that eliminates visual impact on humans completely (Abromas and Kamičaitytè-Virbašienè 2014), and $5 \mathrm{~km}$ away, whereby wind turbines become landscape accents (Abromas and Kamičaitytè-Virbašienè 2014).

Current license permitting authorities do not require a comprehensive study for important bird species, which causes opposition at the courts after the construction of wind farms. Therefore, despite the lack of legal requirement, it was considered essential to analyze important bird areas. Two periodical bird observation datasets (2011-2015 and 2013-2015) were taken into consideration, covering 32.2 and $20.6 \%$ of the country, respectively. Since wind farm licensing takes nearly 5 years, it was deemed appropriate to include sightings reported from 2011 through 2015 in this study. Based on the focal bird habitats for 20 species (center of habitat) and the radius of distribution, areas of concern were created with an additional 100-m buffer (see Supporting Document-2).

Finally, noise does not constitute any constraint for further evaluation, since the average distance needed to ensure compliance with government regulations regarding acceptable noise levels (Supporting Document-2) is well within the mandatory 1-km buffer zone around urban areas (Stage 1 of the Analysis).

Additionally, the results of the final site suitability map were compared to the locations of existing wind farms in Turkey to examine the compatibility of the existing wind farms with the suitable areas and test the validity of our assumptions. However, this comparison did not include environmental criteria since they are not quantitative but more importantly because the majority of the wind farms used in the analysis had already been erected 
before environmental considerations were introduced with relevant legislation.

\section{Results}

\section{Exclusion of infeasible areas}

The aim of this step in the analysis was to remove unsuitable areas from the geographic extent of the study based on the constraints and their associated buffers. Any site that failed to satisfy even one of the exclusion criteria was excluded from further investigation (Fig. 2). Based on the calculation, $10.7 \%$ of the country is covered by urban areas: $6 \%$ by airports, $4 \%$ by protected areas, $0.6 \%$ by faults lines, and $0.2 \%$ by radars can be seen in Fig. 2a to Fig. 2f. The percentage sums up to $21.5 \%$ that corresponds to 17 million ha of the total 78 million ha of Turkey (Fig. 2g). An additional 24\% of the area is not usable for wind energy due to the high altitude $(>1500 \mathrm{~m})$. The remaining $54.5 \%$ is considered suitable at this stage.

\section{Criteria evaluation}

After assessing the technically feasible sites, economically optimum sites were obtained in this section using the pairwise comparisons of the evaluation criteria (Table 3). As a measure of the consistency in the experts' judgment, a consistency ratio (CR) value of $<0.1$ indicates a consistent matrix (Saaty 2008), and with a value of $C R=0.0974$, the evaluations of the present study are considered acceptable.

Table 4 presents pairwise matrix for group decision and priority vectors of criteria, in which values higher than 1 in the upper triangular part of the matrix indicate that the criterion in the row is considered more important than the criterion in the column, while the opposite is true for values lower than 1 . The lower triangular part of the matrix is simply the reciprocal of the upper part, while the last column includes the overall priority values for the criteria. The wind power is at the top of the priority list of criteria. It is followed by the importance of flat terrain and the presence of forest. The land cost is at the bottom of the list. The raw data and scaled distribution of each criterion are illustrated in Fig. $3 \mathrm{a}-\mathrm{h}$. With respect to the wind power criterion, it was seen that differentiation in suitability maps between the two generic turbines was insignificant $\left(R^{2}=\right.$ 0.9959); therefore, the generic turbine (2.1 MW) was used for the remaining calculations. Moreover, as the regulation regarding airports was changed during the study, two different suitability maps with the new and old regulation were developed to illustrate the suitability levels within the feasible sites (Figs. 4 and 5). Figure 8 shows the statistics of suitability classes at 100$\mathrm{m}$ hub heights over Turkey. Following the classification of pixels into classes of low, moderate, and high suitability as (a)

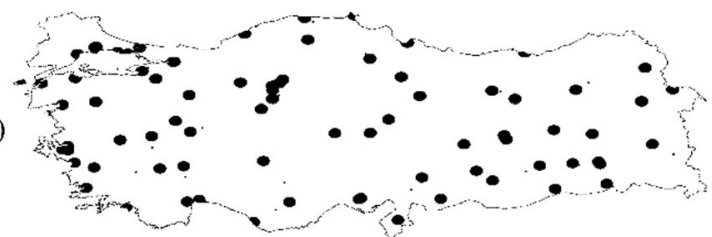

(c)

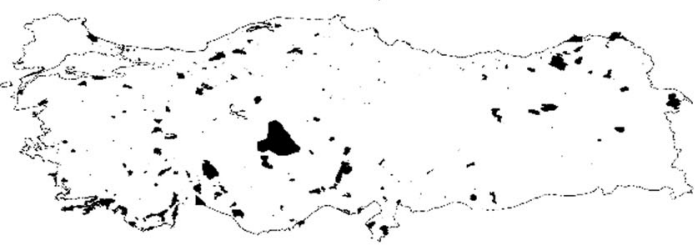

(e)

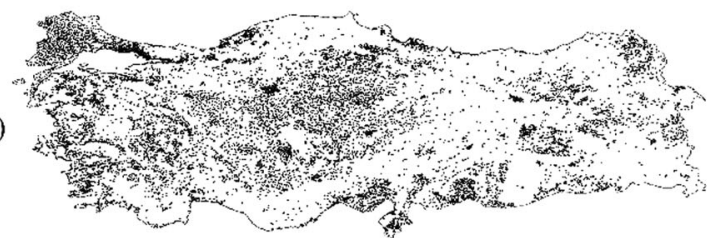

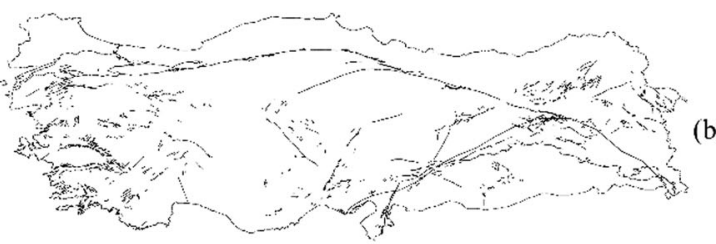

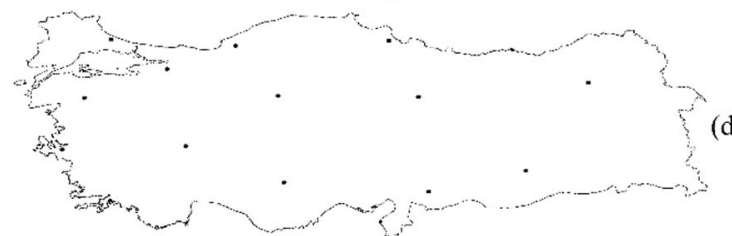

(d)

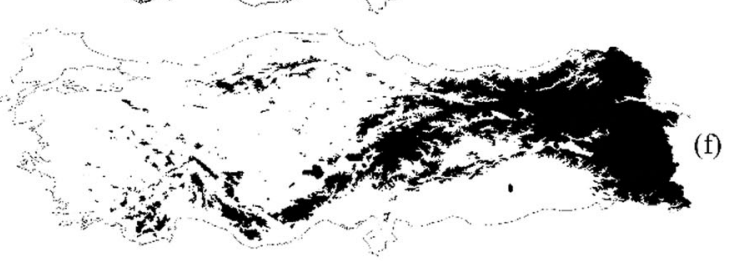

(g)

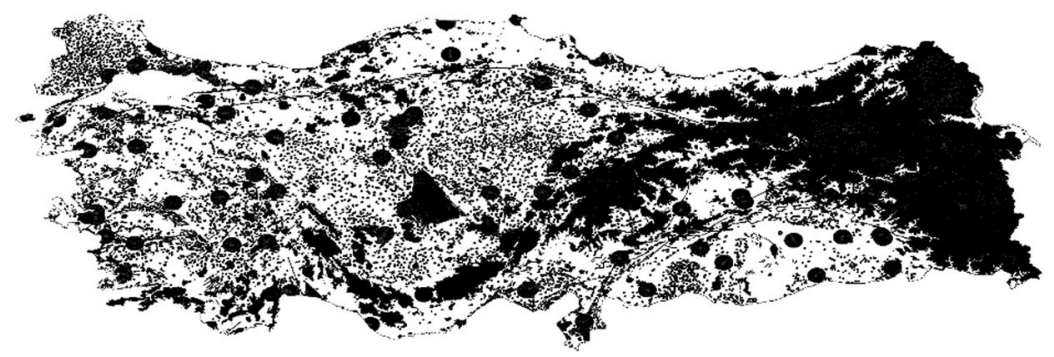

Fig. 2 Excluded zone of a airport, $\mathbf{b}$ fault lines, $\mathbf{c}$ protected area, $\mathbf{d}$ radar, e urban, $\mathbf{f}$ elevation above $1500 \mathrm{~m}$, and $\mathbf{g}$ the total excluded area 
Table 4 Pairwise matrix for group decision and priority vectors of criteria

\begin{tabular}{lllllllll}
\hline & Power & Frozen period & Land cost & Roads & Forest & Grid capacity & Terrain complexity & Priority vector \\
\hline Power & 1.00 & 1.31 & 2.17 & 1.31 & 0.88 & 1.85 & 4.00 & 0.21 \\
Frozen period & 0.76 & 1.00 & 1.94 & 1.48 & 0.87 & 1.68 & 0.50 & 0.14 \\
Land cost & 0.46 & 0.52 & 1.00 & 0.91 & 0.37 & 1.25 & 0.25 & 0.08 \\
Roads & 0.76 & 0.67 & 1.10 & 1.00 & 0.73 & 1.53 & 0.33 & 0.11 \\
Forest & 1.13 & 1.15 & 2.69 & 1.37 & 1.00 & 0.93 & 0.18 & 0.10 \\
Grid capacity & 0.54 & 0.60 & 0.80 & 0.65 & 1.08 & 1.00 & 0.50 & 0.2 \\
Terrain complexity & 0.30 & 2.00 & 4.00 & 3.00 & 0.50 & 2.00 & 1.00 & \\
\hline
\end{tabular}

The diagonal values (all 1.0) were written in italic

described in the "Theory and method" section, it was observed that the majority of the land available for wind farm development is covered by the moderate suitability class $(59.9 \%)$, followed by almost equal areas of highly suitable conditions (20.3\%) and low suitability (19.8\%) (Figs. 6 and 7).

The predominance of the moderately suitable class is owed to the fact that Turkey has an abundance of flat terrain, short frozen periods, areas of low land cost, and moderate wind power potential. This is also reflected in the results of the validation analysis, whereby it was identified that $59.2 \%$ of the existing wind farms are located in moderately suitable areas based on the classification of this study, whereas the minority are placed on low (23.7\%) and highly suitable (17.1\%) areas (Fig. 8), a distribution that matches rather well the proportions of the three classes.
Fig. 3 Priority maps for a power for first generic turbine [kWh], b power for second generic turbine [kWh], c frozen periods [months], d land costs [million $€ /$ ha], e roads [0/1], f forest [million $€ / \mathrm{ha} /$ 20 years], $\mathbf{g}$ grid capacity[\%] (relative to the local availability), and $\mathbf{h}$ terrain complexity [RIX].

Top legend values are scaled 0 to 100 after, and bottom legends are raw data values

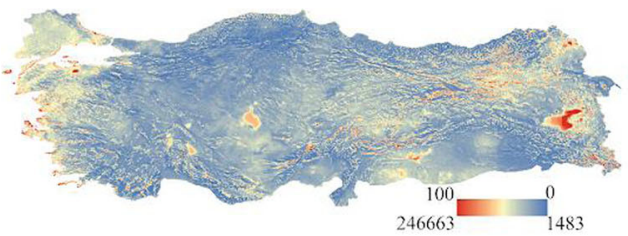

(a)

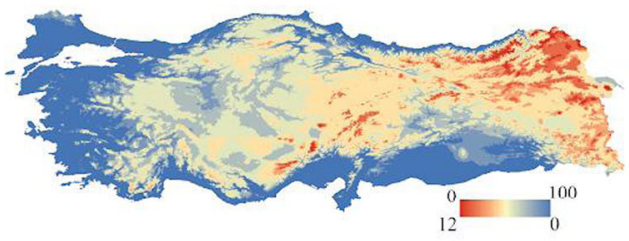

(c)

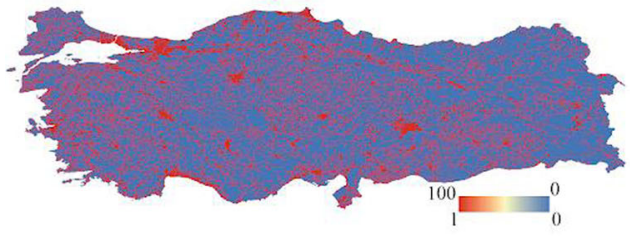

(e)

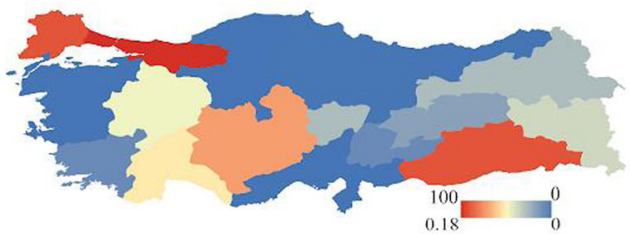

(g)

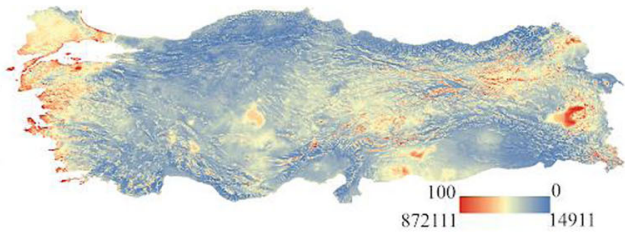

(b)

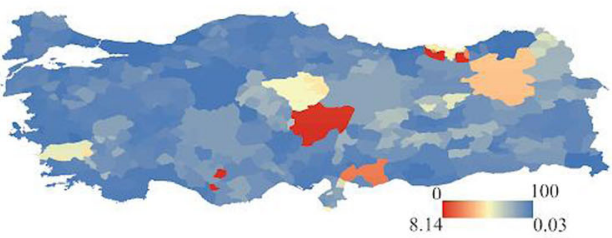

(d)

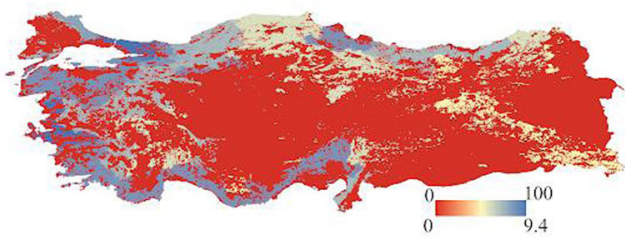

(f)

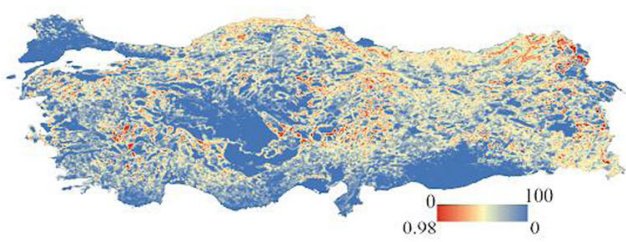

(h) 


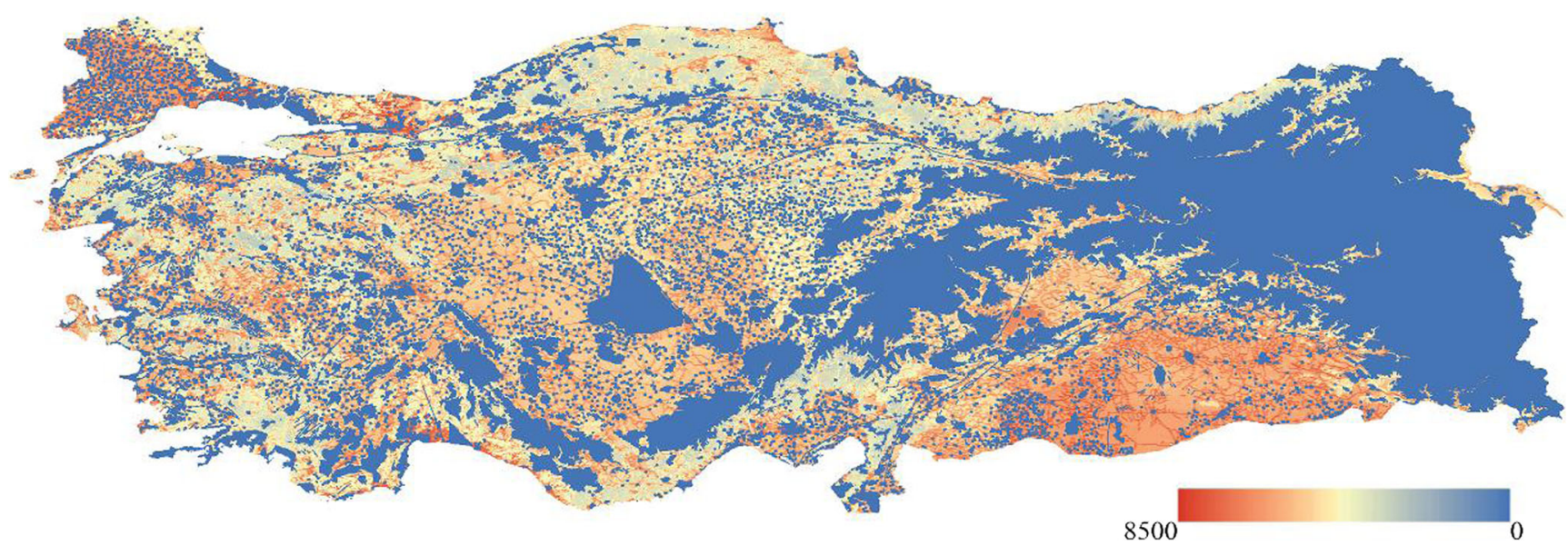

Fig. 4 Overall suitability index with the old airport regulation (2012)

\section{Environmental impact evaluation}

Figure 9a-d shows the areas where environmental issues regarding forests, agricultural land, visual impacts, and important bird areas may arise. The application of a $20-\mathrm{km}$ buffer around urban areas left very little space available for unequivocal wind farm development due to the density of human settlements. It was considered overly conservative/unrealistic and incompatible with the national planning targets for wind energy production. Hence, only the results for the $5-\mathrm{km}$ buffer for urban areas are presented. The resulting area of concern covers 43 million ha (Fig. 9c).

The combined map illustrating areas where any of the primary environmental issues examined in this study is displayed in Fig. 10, which covers an area of 57.6 million ha.

\section{Discussion}

The main output of this study is the developed GIS-based MCDM model which can provide support on effective decision making by relative comparison of wind farm sites. We collected data listed in Table 1 which are to our knowledge is the largest list of factors made for Turkey. Another novelty of our study is the more elaborate processing of some of the factors. For example, in previous MCDM studies (Al-Yahyai et al. 2012; Höfer et al. 2016), wind speed was considered as the main criterion for the wind power calculation. However, the power is also related to air density and the height or the capacity of wind turbines, which we took into account in our calculations to produce a more accurate estimation of wind power potential. Furthermore, the extent of the frost period was also used for the first time in Turkey for site suitability evaluation. For the estimation of the technical and economical suitability, we employed an AHP approach with an expert group with a varied set of backgrounds, striving for a judgement as balanced as possible for the prioritization of the importance of factors. The results of the suitability analysis demonstrate that Turkey is a country rich in wind energy potential. The fact that the distribution of existing wind farms (Fig. 8) among the different suitability classes matches so well, their availability according to our analysis not only validates our choice of factors and weights, but also raises a number of issues. One would expect areas of high suitability to have been

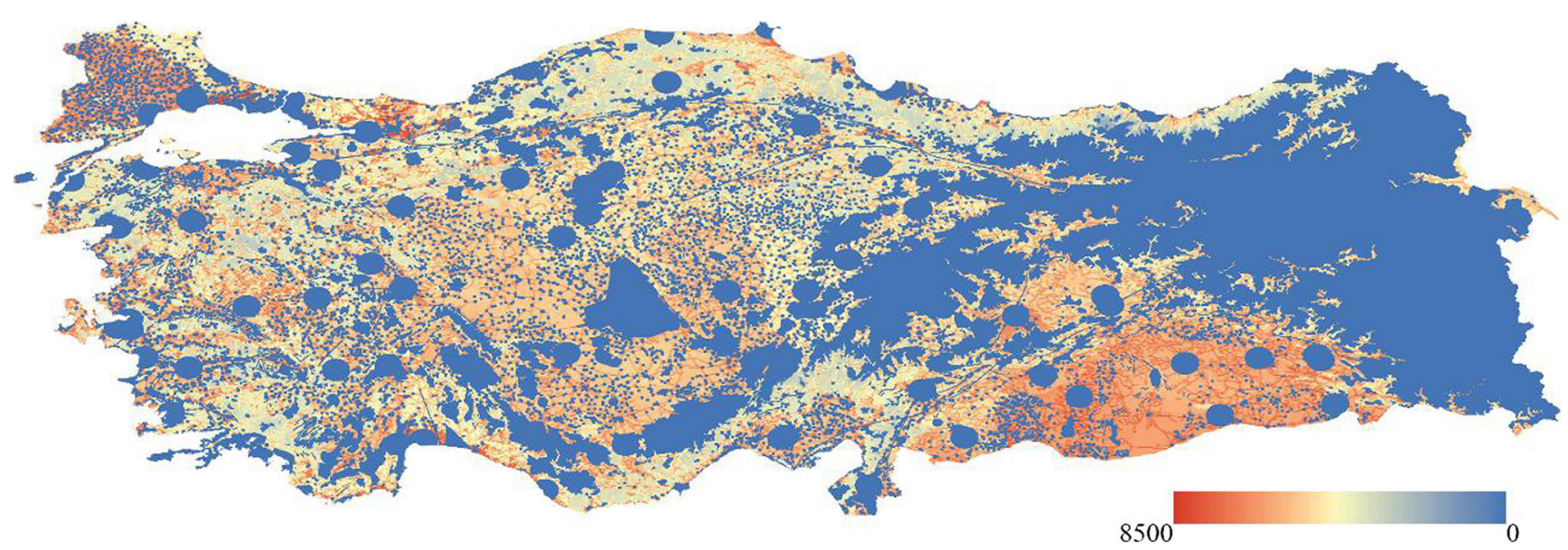

Fig. 5 Overall suitability index with the updated airport regulation (2016) 


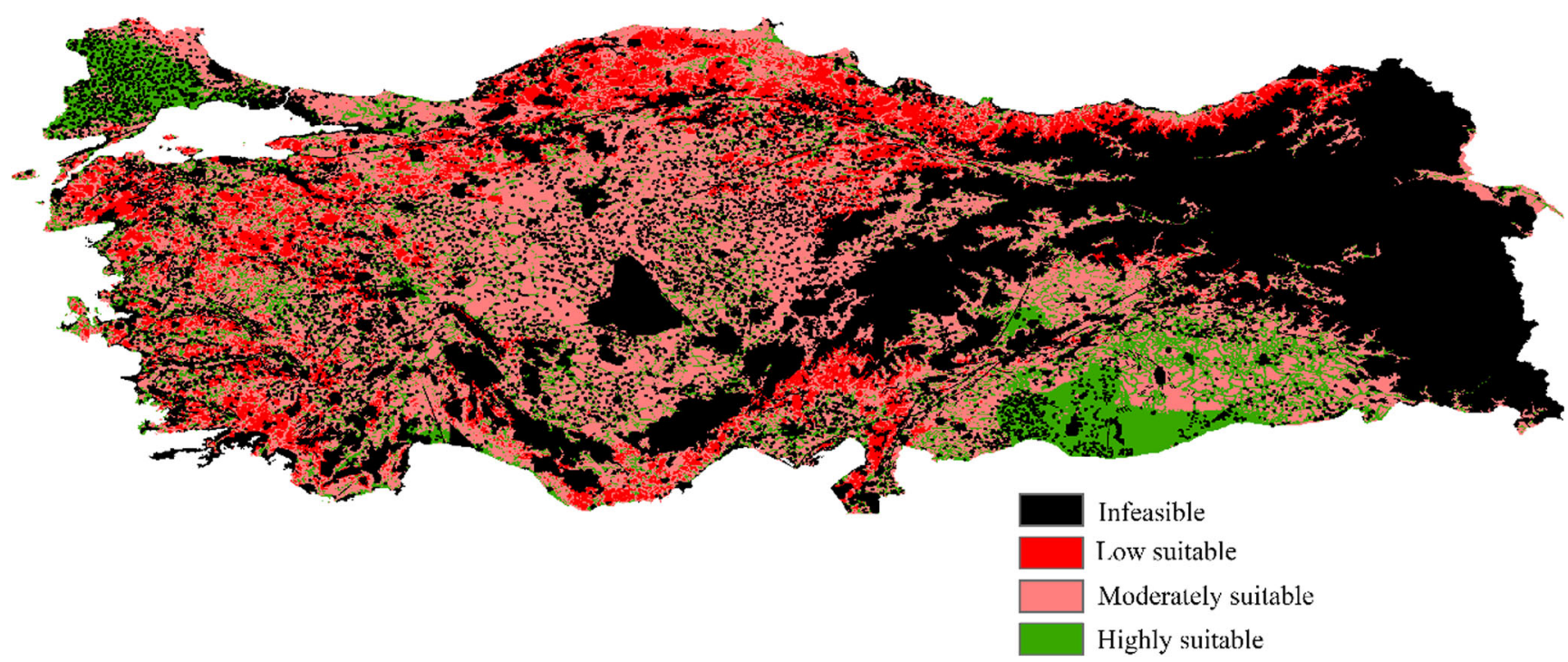

Fig. 6 Overall suitability index with the old airport regulation (2012) in four classes

preferentially exploited thus far and vice-versa for the low suitability areas, but this does not appear to be the case. The inconsistency between the calculated and the realized highly suitable areas could be attributed to the lumping of all regions with elevations between 0 and $1500 \mathrm{~m}$ in one class in our analysis and shows a preference of low-lying areas for wind farm development. On the other hand, the over-representation of exploited low suitability areas may be explained by an over-estimation of their wind potential to begin with.

Due to its modular nature, our methodology provides a flexible and adjustable framework to suit changing legislation as demonstrated by the case of changing airport regulations. It is a tool that can be used by developers and regulators alike since it can provide outputs for different scenarios and accommodate different expert groups.

\section{Usage of output}

To decide in an organized way, three steps (exclusion of infeasible sites, criteria evaluation, and environmental impacts evaluation) were performed. However, it should be noted that although exclusion of infeasible sites and criteria evaluation were combined to remove unpermitted sites, and to rank the remaining sites with respect to their preferabilities, environmental impacts evaluation were not linked with suitability map. Therefore, the decision makers should initially select the three or four best places according to their preferences based on pairwise comparison results. The next stage is to evaluate these sites in terms of environmental aspects. The environmental criteria are either not a subject of a regulation or they are being overcome by special permissions if the developer applies to the related agency/ministry. Most of the time, the issue is resolved with an economical

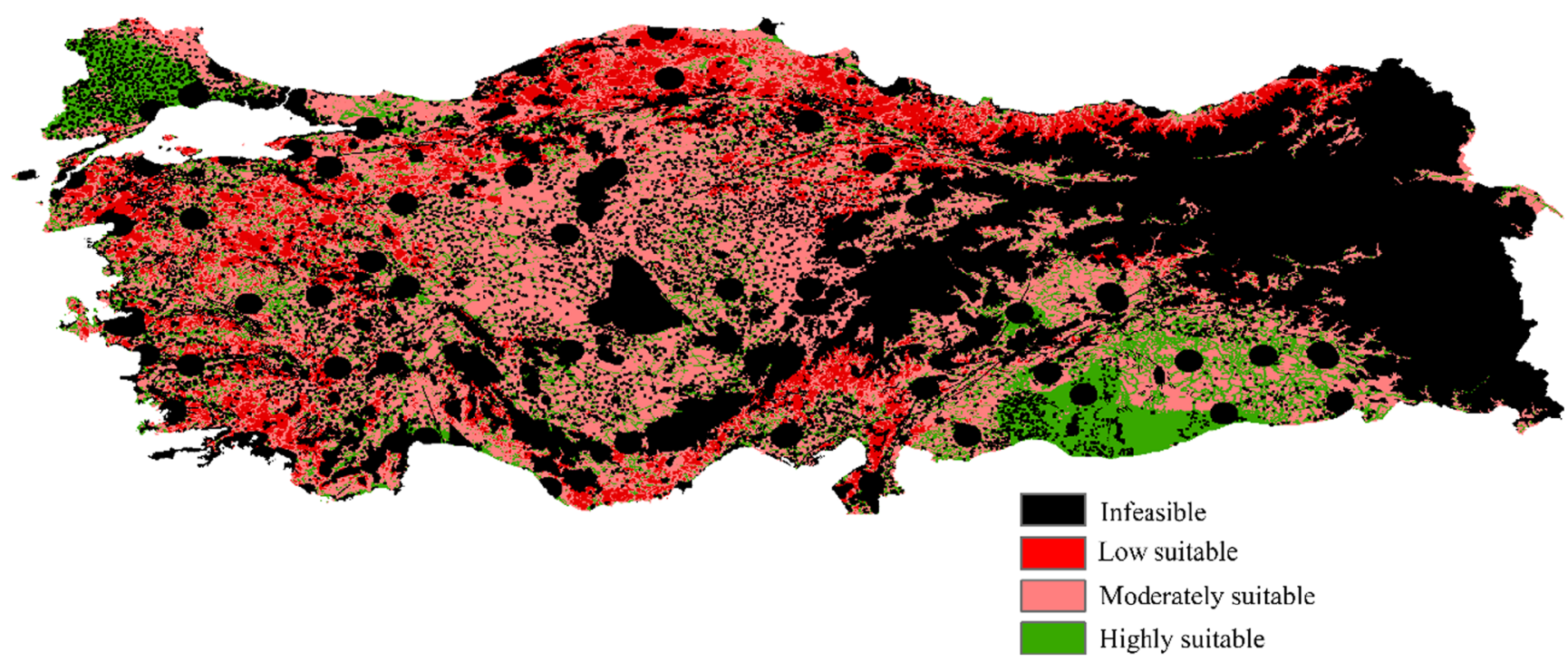

Fig. 7 Overall suitability index with the updated airport regulation (2016) in four classes 
Fig. 8 Distribution of suitability index values and percentages (black) of existing wind farms within selected suitability zones (red)

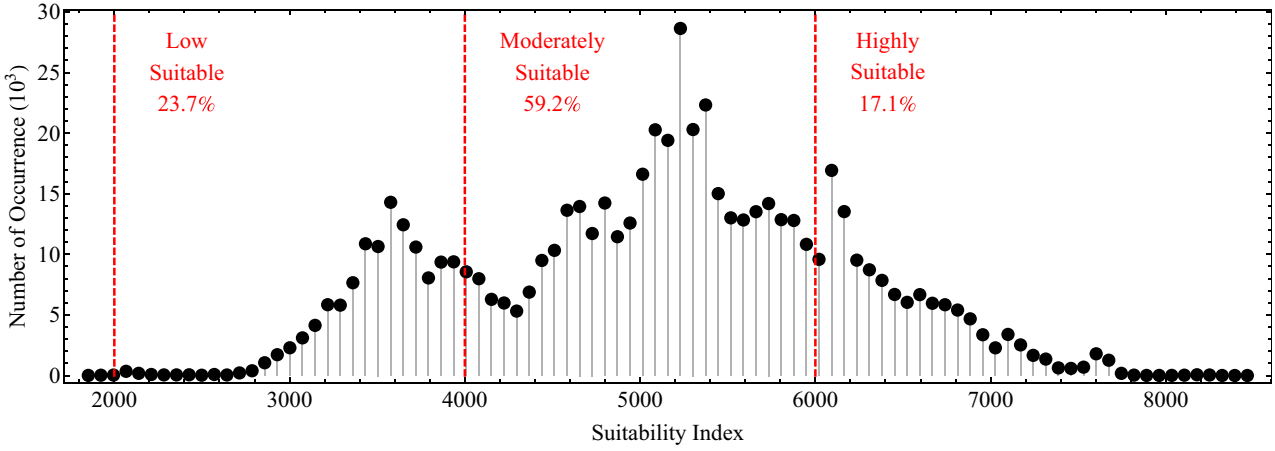

agreement unless the location is not an environmentally protected historic or habitat area. Such procedure, which also changes frequently, creates uncertainties related to budget and decisionmaking steps. Therefore, the decision maker's approaches to this issue are quite decisive. The rationale behind this choice is that all decision makers are not necessarily faced with the same issues/ pressures or do not prioritize environmental concerns in a similar way. For example, while some may be more concerned with visual impacts and establish wind farms away from residential places to minimize impact, others may evaluate visual impact as an unnecessary constraint for site selection and focus on habitat fragmentation instead.

Thus, if three locations have been chosen from a suitability map, and one of them lies in forested terrain, a choice will have to be made among the two remaining locations. Or if all three were in forested terrain, then one should compare the extents of the forested areas.

Several factors that are known to create complications for wind farm sites, such as military districts and radars, bird migration routes, bat habitats, protected forests, world heritage sites, and natural sites, are missing from the site suitability analysis due to security regulations or inaccessibility of the relevant data. The inclusion of these factors will certainly be a requirement for wind farm siting and EIA that could alter considerably the feasible and suitable areas, at least at the local level.

Another limitation of the study is that the buffer zone around river/lakes is not clear in any regulation. Aydin et al. (2010) and Van Haaren and Fthenakis (2011) have taken the distance from water bodies as $400 \mathrm{~m}$ with reference to the study of Baban and Parry (2001). Baban and Parry (2001) collected guidelines from 60 local authorities in the UK by means of a survey and determined a representative distance of $400 \mathrm{~m}$ to water bodies. However, it has not yet been confirmed in the literature. On the other hand, Bennui et al. (2007) and Phuangpornpitak and Tia (2011) excluded a zone of $200 \mathrm{~m}$ from water bodies and main rivers arbitrarily without any reasoning. Turkish legislation of wetland protection also causes some conflicts, since wind power plants investments are allowed by permission. Due to the uncertainties regarding lakes, this study has not taken this matter into consideration as a parameter.

\section{Conclusion}

The wind energy sector needs a planning tool to shorten the planning process, and a visualized suitability map for wind
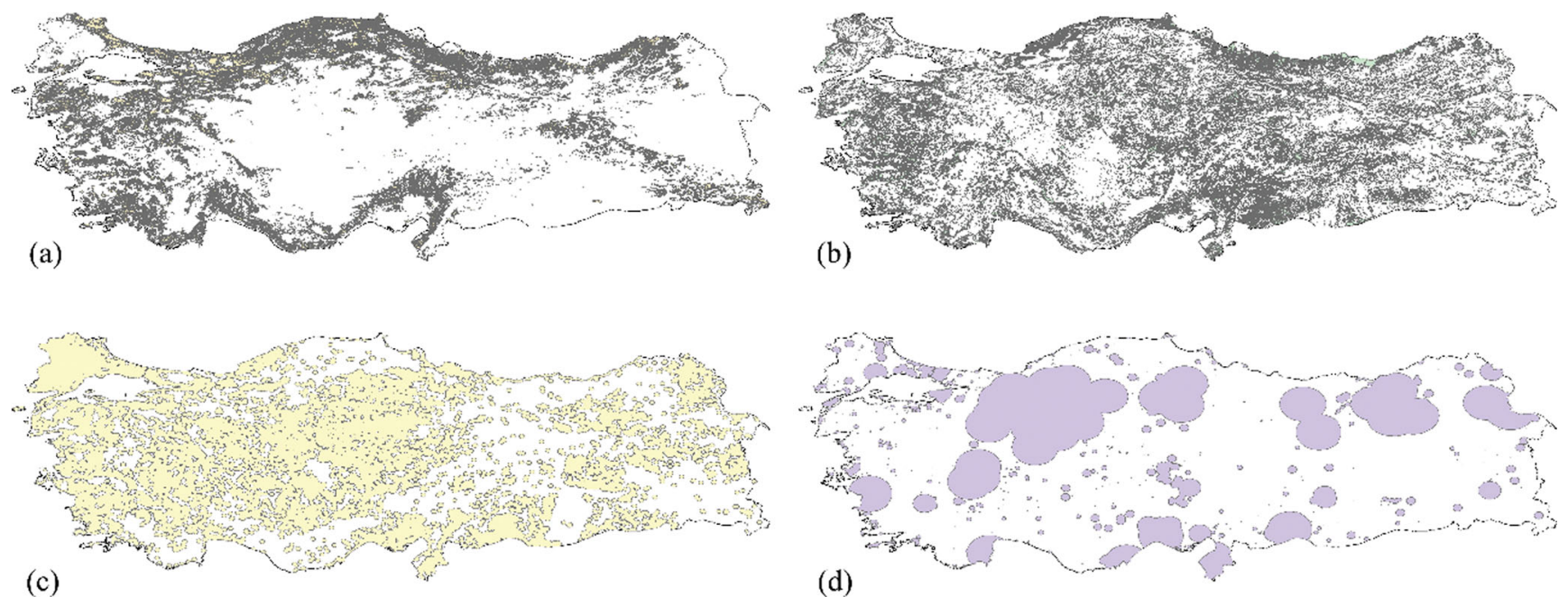

Fig. 9 Areas of concern a forests, $\mathbf{b}$ agricultural lands, $\mathbf{c} 5-\mathrm{km}$ buffer zone around urban areas to avoid visual impact, and $\mathbf{d}$ important bird areas 


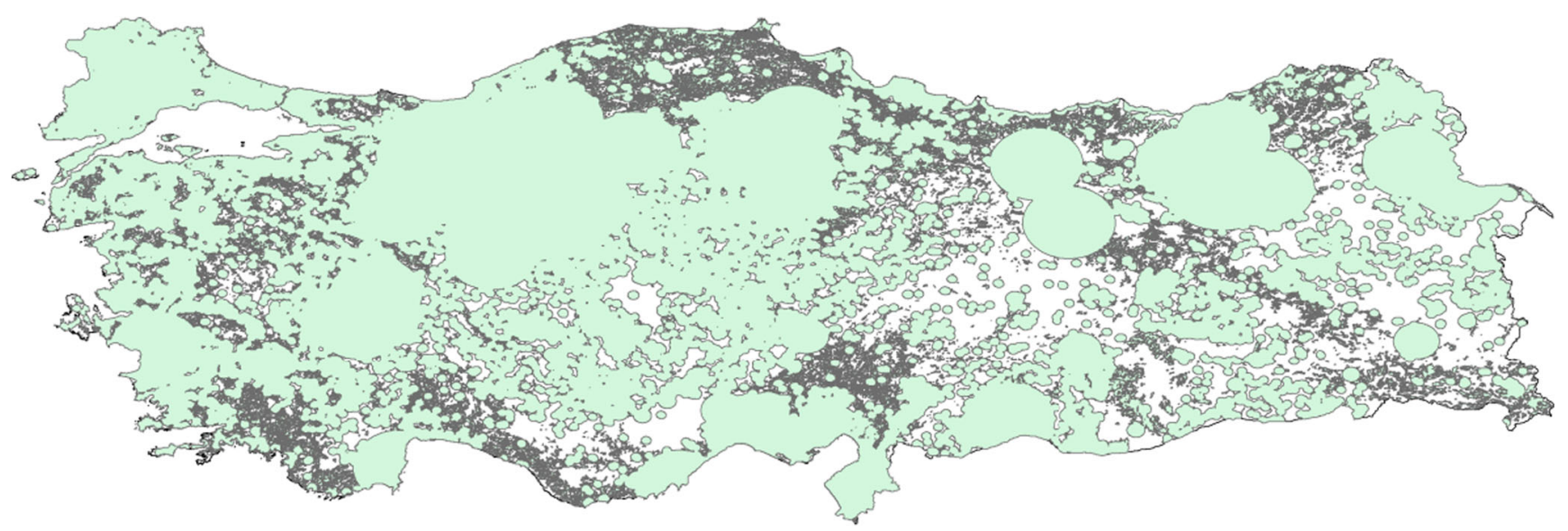

Fig. 10 Areas that should be subject to a full environmental impact analysis

energy installation based on the current regulations and scientific studies. Despite the limitations discussed above, this study succeeded in developing a combination of GIS and MCDM analysis tools by using AHP for site selection modeling in Turkey, as continuous attempt to build a more complete basis for research and development. The GIS model provides to create a dataset for the analysis and demonstration of the suitability of areas for wind farms, whereas the AHP method was applied for assessment of the pairwise importance of criteria on determining suitability of wind farm location.

Based on the results of this study, several recommendations can be made:

- Final spatial analysis of the environmental impact areas shows that the most suitable areas left to install wind farms are mostly at high altitude regions. That means, if the developers would like to stay away from environmental impact issues, they would move on developing wind farms at high altitude regions in the next decade.

- Another possibility to expand wind power capacity and lower the impact on the environment is to re-build already available wind farms with higher capacity wind turbines. Results show that the most of the active wind farms are already using high-capacity locations according to site suitability indexes.

- Although the forested and urban areas are excluded in this study to find the locations with lowest environmental impact, that does not mean that some wind farms would not be erected near or in forested areas or near urban areas. In such cases, the wind turbines will be affected from the high turbulence generated by the forests or urban areas. Therefore, forest and complex terrain modeling for site assessment should be studied and improved by the Turkish developers in order to make more efficient and with lower environmental effect final micro siting.
- With respect to environmental aspects, it should not be forgotten that the number of wind farms has been increasing dramatically to meet the set targets, hence wind farms will occupy more space on top of the 2063 ha which is the current size of the wind farm areas. To minimize the impacts, it is vital that the government and wind energy sector should work together in partnership to provide a single web-based resource to inform future research and project development.

Acknowledgements The authors express their gratitude to Doğa Derneği for providing the necessary data concerning Important Bird Areas. Furthermore, the authors would like to thank two projects which provided some of the ground dataset layers for the study: (i) Wind data from DTU Wind Energy Global Wind Atlas, funded by Danish Energy Agency EUDP 11-II; (ii) elevation, air density, and wind farm data from the TUBITAK project “Adaptation of Uniform Wind Atlases" (114C016).

\section{References}

Abromas J, Kamičaitytè-Virbašienè J (2014) Identification of visual influence zones of wind farms in Lithuania. Rigas Tehniskas Universitates Zinatniskie Raksti 9:43. https://doi.org/10.7250/aup. 2014.006

Al-Yahyai S, Charabi Y, Gastli A, Al-Badi A (2012) Wind farm land suitability indexing using multi-criteria analysis. Renew Energy 44:80-87

Atici KB, Simsek AB, Ulucan A, Tosun MU (2015) A GIS-based multiple criteria decision analysis approach for wind power plant site selection. Util Policy 37:86-96

AWEA (2008) Wind energy for a new era. American Wind Energy Association, Washington, D.C.

Aydin NY, Kentel E, Duzgun S (2010) GIS-based environmental assessment of wind energy systems for spatial planning: a case study from Western Turkey. Renew Sust Energ Rev 14(1):364-373

Baban SM, Parry T (2001) Developing and applying a GISassisted approach to locating wind farms in the UK. Renew Energy 24(1):59-71

Bennui A, Rattanamanee P, Puetpaiboon U, Phukpattaranont P, Chetpattananondh K (2007) Site selection for large wind turbine 
using GIS. PSU-UNS International Conference on Engineering and Environment

Bilgili M, Simsek E (2012) Wind energy potential and turbine installations in Turkey. Energy Sources Part B 7(2):140-151

Bingöl F (2016) TUBITAK project adaptation of uniform wind atlases (114C016)

Coordinates of Special Environmentally Protected Areas (1990) Turkish Republic Official Journal, 20702, 24218, 24055, 27793, 26551, 25339, 28737, 21 November 1990, 2 November 2000, 21 May 2000, 22 December 2010, 13 June 2007, 07 January 2004, 16 August 2013

Coordinates of Special Environmentally Protected Areas (2000) Turkish Republic Official Journal, 20702, 24218, 24055, 27793, 26551, 25339, 28737, 21 November 1990, 2 November 2000, 21 May 2000, 22 December 2010, 13 June 2007, 07 January 2004, 16 August 2013

Coordinates of Special Environmentally Protected Areas (2004) Turkish Republic Official Journal, 20702, 24218, 24055, 27793, 26551, 25339, 28737, 21 November 1990, 2 November 2000, 21 May 2000, 22 December 2010, 13 June 2007, 07 January 2004, 16 August 2013

Coordinates of Special Environmentally Protected Areas (2007) Turkish Republic Official Journal, 20702, 24218, 24055, 27793, 26551, 25339, 28737, 21 November 1990, 2 November 2000, 21 May 2000, 22 December 2010, 13 June 2007, 07 January 2004, 16 August 2013

Coordinates of Special Environmentally Protected Areas (2010) Turkish Republic Official Journal, 20702, 24218, 24055, 27793, 26551, 25339, 28737, 21 November 1990, 2 November 2000, 21 May 2000, 22 December 2010, 13 June 2007, 07 January 2004, 16 August 2013

Coordinates of Special Environmentally Protected Areas (2013) Turkish Republic Official Journal, 20702, 24218, 24055, 27793, 26551, 25339, 28737, 21 November 1990, 2 November 2000, 21 May 2000, 22 December 2010, 13 June 2007, 07 January 2004, 16 August 2013

CORINE (2002) Land Cover Technical Guide - Addendum 2000, EEA, 2000; EEA: I\&CLC2000 Technical Guidelines

Demirtaş R (2005) Kentsel Planlamada Diri Faylar Etrafinda Tampon Bölge Oluşturma Esasları. Ankara University Press, Ankara

DTU (2016) Data from DTU Wind Energy Global Wind Atlas, funded by Danish Energy Agency EUDP 11-II, Globalt Vind Atlas J.nr. 640110347

Dursun B, Gokcol C (2014) Impacts of the renewable energy law on the developments of wind energy in Turkey. Renew Sust Energ Rev 40: 318-325

EMRA (2015) Electricity Generation Licenses. http://lisans.epdk.org.tr/ epvys-web/faces/pages/lisans/elektrikUretim/ elektrikUretimOzetSorgula.xhtml. Accessed 31 July 2015

EWEA (2015). Wind energy scenarios for 2030, European Wind Energy Association

Forest Law (1956) Turkish Republic Official Journal, 9402, 08 October 1956

Gass V, Schmidt J, Strauss F, Schmid E (2013) Assessing the economic wind power potential in Austria. Energy Policy 53:323-330

Georgiou A, Polatidis H, Haralambopoulos D (2012) Wind energy resource assessment and development: decision analysis for site evaluation and application. Energy Sources Part A 34(19):1759-1767

Góralczyk M (2003) Life-cycle assessment in the renewable energy sector. Appl Energy 75(3-4):205-211

Gorsevski PV, Cathcart SC, Mirzaei G, Jamali MM, Ye X, Gomezdelcampo E (2013) A group-based spatial decision support system for wind farm site selection in Northwest Ohio. Energy Policy 55:374-385
Grassi S, Chokani N, Abhari RS (2012) Large scale technical and economical assessment of wind energy potential with a GIS tool: case study Iowa. Energy Policy 45:73-85

Hansen HS (2005) GIS-based multi-criteria analysis of wind farm development. In: H Hauska, Tveite H (eds) ScanGis 2005: Proceedings of the 10th Scandinavian Research Conference on Geographical Information Science. Department of Planning and Environment, Stockholm, pp 75-87

Hijmans RJ, Cameron SE, Parra JL, Jones PG, Jarvis A (2005) Very high resolution interpolated climate surfaces for global land areas. Int $\mathbf{J}$ Climatol 25(15): 1965-1978

Höfer T, Sunak Y, Siddique H, Madlener R (2016) Wind farm siting using a spatial analytic hierarchy process approach: a case study of the Städteregion Aachen. Appl Energy 163:222-243

Hughes G (2012) The performance of wind farms in the United Kingdom and Denmark. Renewable Energy Foundation, London

Ilkılıç C, Aydın H, Behçet R (2011) The current status of wind energy in Turkey and in the world. Energy Policy 39(2):961-967

Jarvis, A. ; H. I. Reuter ; A. Nelson ; E. Guevara (2008) Hole-filled SRTM for the globe Version 4. available from the CGIAR-CSI SRTM 90m Database (http://srtm.csi.cgiar.org)

KOERI. Boğaziçi University Kandilli Obsevatory and Earthquake Research Institute Regional Earthquake-Tsunami Monitoring Center. Retrieved [10 November 2015]

Kumar I, Tyner WE, Sinha KC (2016) Input-output life cycle environmental assessment of greenhouse gas emissions from utility scale wind energy in the United States. Energy Policy 89:294-301

KusBank Veritabanı, Doğa Derneği: Royal Society for the Protection of Birds and BirdLife International. Erciyes Üniversitesi www. kusbank.org. [19 May 2016]

Latinopoulos D, Kechagia K (2015) A GIS-based multi-criteria evaluation for wind farm site selection. A regional scale application in Greece. Renew Energy 78:550-560

Law on National Parks (1983) Turkish Republic Official Journal, 18132, 11 August 1983

Law on Protection of Cultural and Natural Properties (1983) Turkish Republic Official Journal, 18113, 23 July 1983

Law on Wildlife Protection and Development Areas (2004) Turkish Republic Official Journal, 25637, 8 November 2004

Legislation for Construction Criteria Around the Airports (2012) Turkish Republic General Directorate of Civil Navigation

Legistration on Prelicence of Wind and Solar Power (2014) Turkish Republic Official Journal, 29033, 17 June 2014

Lejeune P, Feltz C (2008) Development of a decision support system for setting up a wind energy policy across the Walloon Region (southern Belgium). Renew Energy 33(11):2416-2422

Malczewski J (2010) Multiple criteria decision analysis and geographic information systems. In: Ehrgott M, Figueira RJ, Greco S (eds) Trends in multiple criteria decision analysis. Springer, Boston, pp 369-395

Moeinaddini M, Khorasani N, Danehkar A, Darvishsefat AA (2010) Siting MSW landfill using weighted linear combination and analytical hierarchy process (AHP) methodology in GIS environment (case study: Karaj). Waste Manag 30(5):912-920

Noorollahi Y, Yousefi H, Mohammadi M (2016) Multi-criteria decision support system for wind farm site selection using GIS. Sustain Energy Technol Assess 13:38-50

OpenStreetMap (2015). Available: http://planet.openstreetmap.org [20 June 2016]

Phuangpornpitak N, Tia S (2011) Feasibility study of wind farms under the Thai very small scale renewable energy power producer (VSPP) program. Energy Procedia 9:159-170

Pohekar S, Ramachandran M (2004) Application of multi-criteria decision making to sustainable energy planning — a review. Renew Sust Energ Rev 8(4):365-381 
Regulation for Article 18 of the 17/3 of the Forest Law (2014) Turkish Republic Official Journal, 28976, 18 April 2014

Regulation on Assessment and Management of Environmental Noise (2008) Turkish Republic Official Journal, 26809, 7 March 2008

Regulation on the Technical Assessment of Applications related to Wind Power Generation (2015) Turkish Republic Official Journal, 29508, 20 October 2015

REPA (2007) Turkish wind energy potential atlas. General Directorate of Renewable Energy, Ankara

Saaty TL (1980) The analytic hierarchy process. McGraw-Hill, New York

Saaty TL (2008) Decision making with the analytic hierarchy process. Int J Serv Sci 1(1):83-98

Sánchez-Lozano JM, García-Cascales M, Lamata M (2014) Identification and selection of potential sites for onshore wind farms development in region of Murcia, Spain. Energy 73:311-324

Schallenberg-Rodríguez J, Notario-del Pino J (2014) Evaluation of onshore wind techno-economical potential in regions and islands. Appl Energy 124:117-129

Sliz-Szkliniarz B, Vogt J (2011) GIS-based approach for the evaluation of wind energy potential: a case study for the Kujawsko-Pomorskie Voivodeship. Renew Sust Energ Rev 15(3):1696-1707

Tegou L-I, Polatidis H, Haralambopoulos DA (2010) Environmental management framework for wind farm siting: methodology and case study. J Environ Manag 91(11):2134-2147

TEIAS (2015) Capacity report of electricity distribution companies' production. Turkish Electricity Distribution General Directorate. https:// www.epdk.org.tr/Detay/Download/5023. Accessed 1 March 2016

Tremeac B, Meunier F (2009) Life cycle analysis of 4.5 MW and $250 \mathrm{~W}$ wind turbines. Renew Sust Energ Rev 13(8):2104-2110

TUIK (2014). Turkey in Statistics, Available: http://www.turkstat.gov.tr [31 May 2016]. Turkish Statistical Institute
Turkey (2014) Revenue administration, The minimum land costs, Available: https://intvd.gib.gov.tr/2014_Emlak_Arsa/ [31 October 2015].

TWEA (2015) Turkish Wind Energy Statistics Report-July. Turkish Wind Energy Association. https://www.tureb.com.tr/yayinlar. Accessed 13 Dec 2015

TWEA (2016) Turkish wind energy statistics report-January. Turkish Wind Energy Association. https://www.tureb.com.tr/yayinlar. Accessed 25 May 2016

Twidell J, Weir T (2015) Renewable energy resources, 3rd edn. Taylor and Francis, London

UNESCO (2016a) Camili-United Nations Educational, Scientific and Cultural Organization. http://www.unesco.org/new/en/naturalsciences/environment/ecological-sciences/biosphere-reserves/ europe-north-america/turkey/camili/. Accessed 2 Feb 2016

UNESCO (2016b) World Heritage list. whc.unesco.org/en/list/kml. Accessed 28 Jan 2016

Van Haaren R, Fthenakis V (2011) GIS-based wind farm site selection using spatial multi-criteria analysis (SMCA): evaluating the case for New York State. Renew Sust Energ Rev 15(7):3332-3340

Voivontas D, Assimacopoulos D, Mourelatos A, Corominas J (1998) Evaluation of renewable energy potential using a GIS decision support system. Renew Energy 13(3):333-344

Watson JJ, Hudson MD (2015) Regional scale wind farm and solar farm suitability assessment using GIS-assisted multi-criteria evaluation. Landsc Urban Plan 138:20-31

Weisser D (2007) A guide to life-cycle greenhouse gas (GHG) emissions from electric supply technologies. Energy 32(9):1543-1559

Zimmerling JR, Pomeroy AC, d'Entremont MV, Francis CM (2013) Canadian estimate of bird mortality due to collisions and direct habitat loss associated with wind turbine developments estimation de la mortalité aviaire canadienne attribuable aux collisions et aux pertes directes d'habitat associées à l'éolien. Avian Conserv Ecol $8(2): 10$ 